\title{
Total Synthesis of Linoxepin
}

Synthesis of Natural

Products and

Potential Drugs

Key words

linoxepin

Catellani reaction

domino reaction

palladium catalysis

C-H<smiles>COc1cccc(I)c1O</smiles>

B, $\mathrm{K}_{2} \mathrm{CO}_{3}$

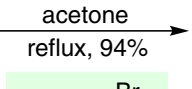

A<smiles>Brc1ccc2c(c1CI)OCO2</smiles>

B<smiles>COc1cccc(I)c1OCc1c(Br)ccc2c1OCO2</smiles>

$\mathrm{Pd}(\mathrm{OAc})_{2}$ ( 0.1 equiv) $\mathrm{Ph}_{3} \mathrm{P}(0.22$ equiv)

D (5 equiv), E (5 equiv) norbornene (5 equiv)

$\mathrm{Cs}_{2} \mathrm{CO}_{3}$ (5 equiv) DMF, $90{ }^{\circ} \mathrm{C}, 5 \mathrm{~h}, 89 \%$

Catellani reaction<smiles>O=C1C[C@H](CI)CO1</smiles><smiles>C=COC(=O)OC</smiles>

$\mathrm{E}$
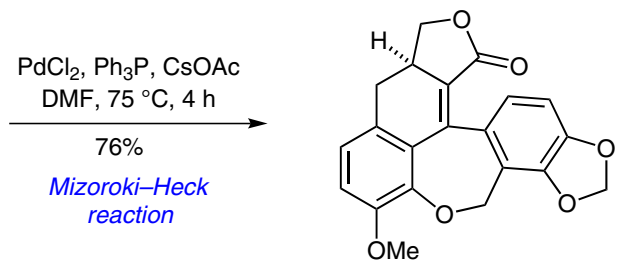

$(+)$-Linoxepin
Significance: Lautens and co-workers report the synthesis of linoxepin, a lignin isolated from Linum perennne L. (Linaceae). The elegant strategy relies on the Catellani reaction, in which a strained olefin (norbornene) is used to couple an iodoarene, an alkyl halide, and a terminal olefin using palladium catalysis. This is the first application of the Catellani reaction in the synthesis of a natural product and underscores the power of processes that form multiple bonds in a single step. In this context, it is worth highlighting the recent synthesis of linoxepin by Tietze and co-workers (Angew.

Chem. Int. Ed. 2013, 52, 3191), which relies on a different palladium-catalyzed domino reaction.
Comment: Alkylation of phenol A with benzyl iodide B gave Catellani precursor C in 94\% yield. The norbornene-mediated domino process involving aryl iodide $\mathbf{C}$, enantiopure alkyl iodide $\mathbf{D}$ and acrylate E delivered key intermediate $\mathbf{F}$ in 89\% yield. Oxidative cleavage of the olefin followed by $\mathrm{TiCl}_{4}$-promoted aldol condensation furnished $\mathbf{G}$, which in the presence of catalytic amounts of a palladium catalyst underwent a Mizoroki-Heck reaction to give (+)-linoxepin in $76 \%$ yield. 